\title{
Study of Cost Economics of Management of Chilli Mites through Abamectin 1.8 EC
}

\author{
Akhilesh Kumar ${ }^{1}$, Alpana Sharma ${ }^{2}$, Neelu Vishwakarma ${ }^{3}$ and Mrigendra Singh ${ }^{2}$ \\ ${ }^{1}$ JNKVV-Krishi Vigyan Kendra, CoA, Rewa-486 001 (M.P.), India \\ ${ }^{2} J N K V V$-Krishi Vigyan Kendra, Shahdol (MP), India \\ ${ }^{3} J N K V V$-Krishi Vigyan Kendra, Jabalpur (MP), India \\ *Corresponding author
}

\begin{abstract}
A B S T R A C T
\end{abstract}
\section{Keywords}

Chilli, Abamectin 1.8EC,

Polyphagotarsonemus

latus, Yield and B: C

ratio

Article Info

Accepted:

10 August 2018

Available Online:

10 September 2018
The study was conducted on the assessment of management of chilli mites Polyphagotarsonemus latus Banks using Abamectin 1.8 EC. The study was carried as OnFarm -Trials at farmer's fields in Sinduri village of Shahdol district (M.P.) during Kharif (2012-2013). Two sprays of Abamectin 1.8 EC @ $750 \mathrm{ml} / \mathrm{ha}$ at 15 days interval were applied on farmers fields as research practice (RP) and compared with farmers practise fields of indiscriminate use of insecticides. The Abamectin 1.8 EC treated fields showed 0.75 mites/leaf while, farmers practise fields showed 1.80 mites/leaf. The technology assessed showed promising and positive results with yield of 120 (q/ha) and net return of 139650 (Rs./ha) as compared to farmers practices of yield 78 (q/ha) and net return of 76100 (Rs./ha) of chilli crop. Thus, the technology was found suitable for mites management in Chilli showing reduction in mites infestation. The benefit cost ratios (B: C) were found to be 2.83 and 2.19, respectively in Abamectin 1.8 EC treated fields and farmers practice fields, respectively.

\section{Introduction}

Chilli (Capsicum annuum L.) is one of the important vegetable crops grown throughout the tropics and warm temperate regions of the world.

Although there is a scope to enhance the productivity of chilli, a number of limiting factors have been attributed for the low productivity, among which, the damage caused by insect pests and mites is of paramount importance. India accounts for about $25 \%$ of the world total production of chilli (Nayaka et al., 2009) and it is a major exporter of chilli to Sri Lanka, USA, Nepal, Mexico and Bangladesh (Jagtap et al., 2012).

The yellow mite, Polyphagotarsonemus latus Banks and thrips, Scirtothrips dorsalis Hood are two important sucking pests of chilli with $30-55 \%$ severity causing extensive leaf curl and yield loss (Rai et al., 2007). The tarsonemid mites are an important pest and infested leaves become bronzed with downcurling margins, buds are aborted and flowers distorted, shoots grow twisted and fruit may be misshapen and russeted and yield loss goes 
up to 94 per cent under favourable conditions. Imidacloprid, a systemic insecticide of neonicotinoids group recommended in chilli is known to cause resurgence in mite (Srinivasulu et al., 2002).

Abamectin is a natural fermentation product of the soil bacterium Streptomyces avermitilis (Omura and Shiomi, 2007 and Pitterna et al., 2009). Furthermore, Abamectin is a blend of avermectins $\mathrm{B} 1 \mathrm{a}$ and $\mathrm{B} 1 \mathrm{~b}$, which contain at least about $80 \%$ avermectin Bla and 20\% avermectin Blb (Pitterna, et al., 2009). These two components, Bla and Blb, have very similar biological and toxicological properties. The Abamectin 1.8 EC is antibiotic insecticide and acaricide with action of contact poisoning, stomach poisoning and feeble fumigation. It has distinct diffusion effect on the leaves. After applied, the liquor rapidly impregnate into epidermal tissue and forming the second peak time of efficacy.

\section{Materials and Methods}

Management of mites in chilli crop (variety Kashi Anmol) through Abamectin 1.8 EC was carried as Five Trials under OFT. The work was carried in irrigated fields each of 2000 sq. $\mathrm{m}$ area in village Sinduri of Shahdol District, (M.P.) in Kharif (2012-2013). The technology was to evaluate the performance of Abamectin $1.8 \mathrm{EC} @ 750 \mathrm{ml} / \mathrm{ha}$ two sprays at 15 days interval, and compared with farmers practices of indiscriminate use of insecticides. The soil was sandy loam in texture. Raising of chilli crop was done as per standard agronomic practices. Chilli crop was raised in nursery and 22 day old seedlings were transplanted at a spacing of $50 \mathrm{~cm} \times 50 \mathrm{~cm}$. Further, the mite population were studied by selecting and tagging five plants randomly from each plot. The mite population were counted from different parts like upper, middle and lower portion of the plant leaf and their mean population were calculated per leaf.

\section{Cost benefit ratio}

The data were tabulated and calculated on the basis of their yield performance. The fruit yield from farmer's field was recorded and computed as quintal per hectare $(\mathrm{q} / \mathrm{ha})$. The cost-benefit ratio (CBR) of different farmers was calculated by estimating their cost of cultivation and their returns from fruit yield and computing them to per hectare piece of land. The average market price of chilli prevalent during the studied period was 18 (Rs/Kg). Cost benefit ratio was calculated using the following formula:

Average gross return -

Average cost of cultivation

$\mathrm{CBR}=$

Average cost of cultivation

\section{Results and Discussion}

Table 1 and Figure 1a, 1b and 1c showed the efficacy of Abamectin 1.8 EC i.e. effectiveness of acaricide against chilli mite, Polyphagotarsonemus latus Banks over the farmers practice. The adults and nymphs of mites generally suck sap from leaves, petioles and tender twigs. The margin of the young leaves curled downwards in an inverted boat shaped manner. The leaves look shiny, and silvery lining was recorded on the ventral surface. However, the older leaves and petioles were found elongated. In severely infested plant, leaves and terminal twigs become hardened, twisted and thickened.

Infested plant produced very small sized leaves. In such a plant most of the young fruits look silvery and shiny, and in later stage the fruits become cracked and deformed (Mondal and Mondal, 2012). The post treatment effect, after sprayed, indicated a significant reduction in the population of mites in the acaricide treated plot (Research practice) than untreated control (farmer practice). 
Table.1 Economics viability of Abamectin 1.8 E.C. for mites management in chilli crop

\begin{tabular}{|c|c|c|c|c|c|c|c|c|c|c|c|c|c|c|c|}
\hline \multicolumn{2}{|c|}{$\begin{array}{l}\text { Av. Cost of } \\
\text { cultivation } \\
(\text { Rs/ha) }\end{array}$} & \multicolumn{2}{|c|}{$\begin{array}{l}\text { No. of } \\
\text { (mites/leaf) }\end{array}$} & \multicolumn{2}{|c|}{$\begin{array}{l}\text { Reduction in } \\
\text { mites } \\
\text { infestation } \\
(\%)\end{array}$} & \multicolumn{2}{|c|}{ Yield (q/ha) } & \multicolumn{2}{|c|}{$\begin{array}{l}\text { Yield } \\
\text { enhancemen } \\
t(\%)\end{array}$} & \multicolumn{2}{|c|}{$\begin{array}{l}\text { Average Gross } \\
\text { Return (Rs/ha) }\end{array}$} & \multicolumn{2}{|c|}{$\begin{array}{l}\text { Av Net Return } \\
\text { (Rs/ha) }\end{array}$} & \multicolumn{2}{|l|}{$\begin{array}{l}\text { B:C } \\
\text { Ratio }\end{array}$} \\
\hline $\begin{array}{l}\text { FP } \\
(\mathrm{T} 1)\end{array}$ & $\begin{array}{l}\text { RP } \\
\text { (T2) }\end{array}$ & $\begin{array}{l}\text { FP } \\
(\mathrm{T} 1)\end{array}$ & $\begin{array}{l}\mathbf{R P} \\
(\mathrm{T} 2)\end{array}$ & $\begin{array}{l}\text { FP } \\
(\mathrm{T} 1)\end{array}$ & $\begin{array}{l}\text { RP } \\
\text { (T2) }\end{array}$ & $\begin{array}{l}\text { FP } \\
\text { (T1) }\end{array}$ & $\begin{array}{l}\text { RP } \\
(\mathrm{T} 2)\end{array}$ & $\begin{array}{l}\text { FP } \\
\text { (T1) }\end{array}$ & $\begin{array}{l}\text { RP } \\
(\mathrm{T} 2)\end{array}$ & $\begin{array}{l}\text { FP } \\
(\mathrm{T} 1)\end{array}$ & $\begin{array}{l}\text { RP } \\
(\mathrm{T} 2)\end{array}$ & $\begin{array}{l}\text { FP } \\
(\mathbf{T} 1)\end{array}$ & $\begin{array}{l}\text { FP } \\
(\mathrm{T} 2)\end{array}$ & $\begin{array}{l}\text { FP } \\
\text { (T1) }\end{array}$ & $\begin{array}{l}\text { RP } \\
\text { (T2) }\end{array}$ \\
\hline 63900 & 76350 & 1.8 & 0.75 & - & 58.33 & 78 & 120 & - & 35 & 140000 & 216000 & 76100 & 139650 & 2.19 & 2.83 \\
\hline
\end{tabular}

Fig.1a

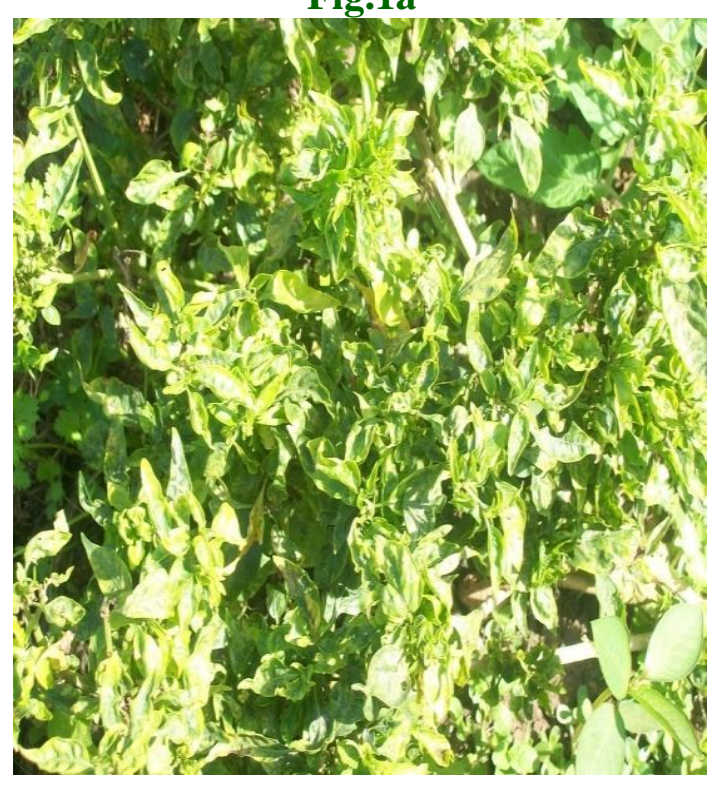

MITES AFFECTED PLANTS
Fig.1b

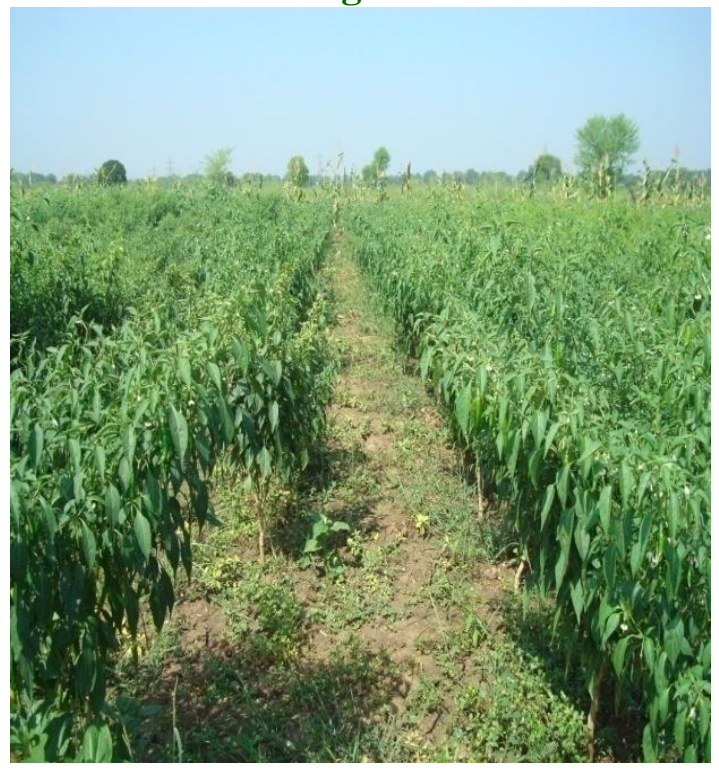

\section{HEALTHY PLANTS}

Fig.1c

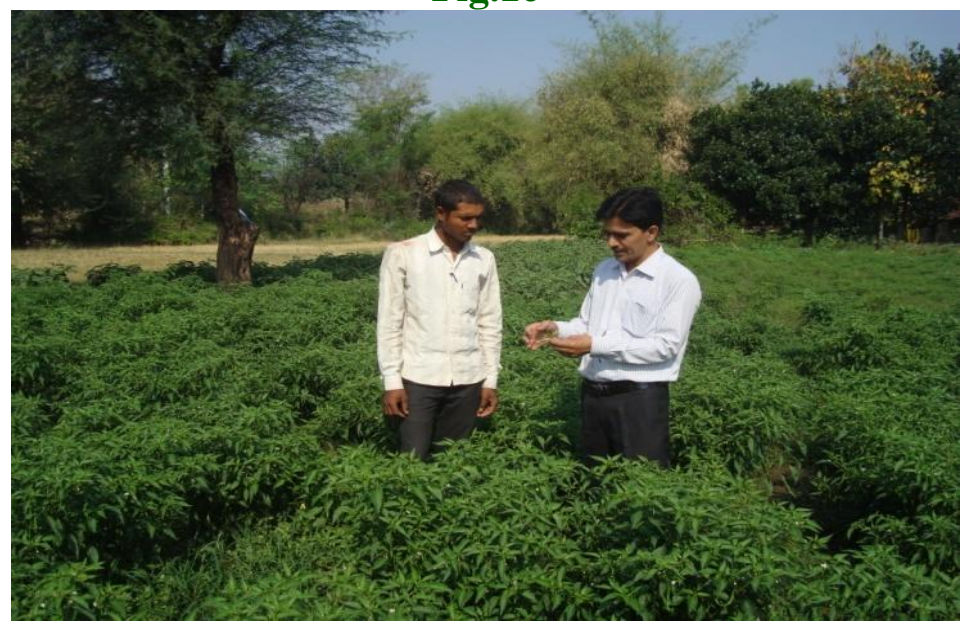

FARMERS -SCIENTIST INTERACTION 
The average number of mites varied from 0.75 to 1.80 (mites/leaf). The Abamectin 1.8 EC treated fields showed 0.75 (mites/leaf) while, farmers practise fields showed 1.80 (mites/leaf) and promising yield of 120 (q/ha) giving a net return of 139650 (Rs./ha) as compared to farmers practices yield of 78 (q/ha) and net return of 76100 (Rs./ ha). The assessed technology was found suitable for mites management in chilli with reduction in the infestation considerably. The benefit cost ratios were 2.83 and 2.19, respectively in Abamectin 1.8 EC treated fields and farmers practices fields respectively. Thus, the technology of two sprays of Abamectin 1.8 EC at 15 days interval was found to be economically viable for management of crop losses in chilly by mites in comparison with farmers practices. Abamectin 1.8 EC @ 750 $\mathrm{ml} / \mathrm{ha}$ was found superior over the farmer practice with a percent reduction of 58.33 in mites population and yield enhancement up to $35 \%$ over farmers practice. The Abamectin 1.8 EC was very effective in reducing the mites infestation in chilli crop as well as also increasing the fruit yield as also reported by earlier scientist Mondal and Mondal (2012), Nandini et al., (2012) and Sujay et. al. (2015).

Economics viability of Abamectin 1.8 E.C. for mites management in chilli crop are presented in Table 1. Based on average fruit yield and prevalent market price of chilli Cost Benefit Cost Ratio (B: C) was calculated. The benefit cost ratio was found to be 2.83 in Abamectin 1.8 EC treated fields and 2.19 in farmers practice fields. Vishwakarma et al., (2010) also calculated B: C ratio for different treatments against yellow mite in chilli crop.

\section{References}

Jagtap PP, Shingane US and Kuikarani KP. 2012. Economics of Chilli Production in India. African Journal of Basic Applied Sciences 4:161-164.
Mondal B. and Mondal P. 2012. Ecofriendly pest management practices for leaf curl complex of chilli (Capsicum annuum L.). Journal of Biopesticides 5 (Supplementary): 115-118.

Nandini G, RS, Mantur SM and Patil RK. 2012. Evaluation of biopesticides against Capsicum pests under protected cultivation. Annals of Plant Protection Sciences 20(1): 120-25.

Nayaka CS, Udaya AC, Niranjan SR, Prakash HS and Mortensen CN. 2009. Anthracnose disease of chilli pepper. Asian Seed Health Centre Technical Bulletin pp 1-13.

Omura S and Shiomi K. 2007. Discovery, chemistry, and chemical biology of microbial products. Pure and Applied Chemistry 79: 581-591.

Pitterna T, Cassayre J, Hüter OF, Jung PM, Maienfisch P, et al., 2009. New ventures in the chemistry of avermectins. Bioorganic \& Medicinal Chemistry 17: 4085-4095.

Rai AB, Satpathy S, Gracy, RG, Shivalingaswamy, TM and Rai $M$. 2007. Yellow mite (Polyphagotarsonemus latus Banks) menace in chilli crop. Vegetable Science 34(1): 1-13.

Srinivasulu P, Naidu VG and Rao NV. 2002. Evaluation of different pesticides for the control of yellow mite, Polyphagotarsonemus latus (Banks) on chilli. Journal of Applied Zoological Research 13(1): 71-72.

Sujay YH, Giraddi RS and Udikeri SS. 2015. Efficacy of New Molecules and Botanicals against Chilli (Capsicum annuum L.) Pests. The Madras Agricultural Journal 102 (10-12): 348352.

Vishakarma R, Ghatak, SS and Mondal S. 2010. Bio-efficacy of some organic formulations and novel pesticides against chilli mite, 
Polyphagotarsonemus latus Banks

Symposium-cum Workshop in (Tarsonemidae). In: International Acarology, Kalyani, India, 78 P.

\section{How to cite this article:}

Akhilesh Kumar, Alpana Sharma, Neelu Vishwakarma and Mrigendra Singh. 2018. Study of Cost Economics of Management of Chilli Mites through Abamectin 1.8 EC. Int.J.Curr.Microbiol.App.Sci. 7(09): 1659-1663. doi: https://doi.org/10.20546/ijcmas.2018.709.200 